\title{
Life Experience of Patients With Coronary Heart Disease Post Percutaneous Coronary Intervention (PCI) in Bulukumba Regency
}

\author{
Annisya Cahya Amsani ${ }^{1}$, Muriyati $^{*}{ }^{*}$ Amirullah $^{3}$ \\ S1 Nursing Study, Stikes Panrita Husada Bulukumba, Indonesia1 \\ Medical Surgical Nursing, Stikes Panrita Husada Bulukumba, Indonesia2 \\ Medical Surgical Nursing, Stikes Panrita Husada Bulukumba, Indonesia3 \\ *Corresponding Autor : $\underline{\text { muriyatirisman@gmail.com }}$
}

\begin{abstract}
Coronary Heart Disease is a disease that interferes with heart function due to narrowing that occurs due to fatty deposits or plaque in the coronary arteries that block blood flow to the heart. The existence of a non-surgical PCI (Percutaneous Coronary Intervention) procedure which dilates blood vessels with the installation of a stent, makes many patients with coronary heart disease choose to undergo this procedure. The high number of choices for PCI action and the lack of research that discusses the life experiences of patients who have undergone PCI, makes researchers interested in conducting this study. This study aims to determine the life experiences of patients with coronary heart disease who have undergone percutaneous coronary intervention in Bulukumba Regency. The data in this study were collected through indepth interviews on selected subjects (In-depth Interview) and analyzed using Thematic Analysis. Researchers found 4 themes from the results of data analysis. The themes are: (1) Lifestyle, sub-themes: diet, smoking, physical activity and medication adherence. (2) Psychological responses, sub themes: feelings of anxiety and worry, emotions and stress. (3) Forms of Support, sub-themes: family support, spiritual support. (4) Quality of Life for Post PCI Patients, sub-themes: feeling back to normal, changes in sleep patterns and pain. There are 4 themes found in this study. It is hoped that patients with coronary heart disease who have undergone PCI procedures will continue to increase their motivation to live a better life.
\end{abstract}

Keywords : Life Experience, Coronary Heart Disease, Percutaneous Coronary Intervention (PCI)

\section{INTRODUCTION}

Until now, cardiovascular disease is still a global threat and Coronary Heart Disease (CHD) has become one of the main problems causing death in the world. The World Health Organization (WHO), in 2018 showed that coronary heart disease has become a major contributor to death worldwide and is a world health problem with the highest mortality, claiming 7 million people per year (Susilo, 2015). Based on data from the Basic Health Research (Riskesdas) in 2018, the incidence of cardiovascular and blood vessel disease is increasing every year. About 15 out of 1000 people or about 4.2 million people in Indonesia suffer from heart disease. This disease also mostly attacks the productive age, therefore the level of morbidity and mortality becomes a fairly large burden for the community, especially in the economic and social fields (PERKI, 2020).

Based on interviews with doctors diagnosed in Indonesia, the prevalence of 
coronary heart disease in Indonesia is around $0.5 \%$, with the prevalence of coronary heart disease symptoms, East Nusa Tenggara ranks first at 4.4\%, followed by Central Sulawesi 3.8\%, South Sulawesi 2.9\% and West Sulawesi 2.6\% (Arni \& Wagustina, 2019). Quoted from the official website of the Ministry of Health (2019), the prevalence of coronary heart disease in terms of gender, the prevalence in women is higher $(1.6 \%)$ compared to men (1.3\%). If viewed from the side of work, government officials such as PNS/TNI/POLRI/BUMN/BUMD and workers with high activity have a prevalence of coronary heart disease of $2.7 \%$. Likewise, when viewed from the place of residence, it was found that the population in urban areas had a prevalence of $1.6 \%$ higher than that of rural residents whose prevalence was only $1.3 \%$.

Data from the H. Andi Sultan Daeng Radja Regional General Hospital (RSUD) Bulukumba Regency from 2018 to 2019 recorded around 89 people diagnosed with Coronary Heart Disease. There are many risk factors that can lead to coronary heart disease. These factors can be divided into 2 factors, namely: risk factors that cannot be prevented include family history, gender and age factors. While the risk factors that can be prevented include obesity, smoking, hypertension, diabetes mellitus, and lifestyle (Muthmainnah et al., 2019). The Global Burden of Disease explains that management for patients with coronary heart disease can be through revascularization therapy. These therapies include Percutaneous Coronary Intervention (PCI) with balloon placement (stent) and Coronary Artery Bypass Graft (CABG) or commonly referred to as coronary artery graft surgery (Oktaviono, 2020).

Based on a study in England, showing that percutaneous coronary intervention has provided many benefits both in terms of risk, anxiety levels, physical abilities, success rates, quality of life, and lower mortality rates (Head \& Bates, 2018). Another study also showed that patients who had percutaneous coronary intervention had a better quality of life by 50\% (Ully Hutagulung et al., 2014). Based on the phenomenon of an increase in the incidence of cardiovascular disease, especially coronary heart disease, as well as the increasing number of patients who choose to perform stent placement with percutaneous coronary intervention procedures in the area around the researcher, and the lack of research that discusses the life experiences of patients with coronary heart disease with percutaneous coronary intervention. qualitatively, the researchers are interested in conducting research on "Life Experiences of Post Percutaneous Coronary Intervention Patients with Coronary Heart Disease in Bulukumba Regency". 


\section{METHODS}

This research is a qualitative research with a phenomenological design. This research was conducted from April to May 2021 in Bulukumba Regency. In this study, there were 6 respondents who were obtained using the snowball sampling technique. The instruments used are question sheets and interviews. The questions that have been prepared are then consulted with qualitative research experts. This study also uses recorders and notes as research aids. The data analysis technique in this study uses thematic analysis, namely the analysis used by researchers to find out the main problem and be able to determine the theme according to the data found during the interview.

\section{RESULTS AND DISCUSSION}

Table 1. Characteristics of Patients with Coronary Heart Disease Post Percutaneous Coronary Intervention in Bulukumba District.

\begin{tabular}{ccccc}
\hline Informan Code & Initials & Gender & Age & Education \\
\hline P1 & Mr. I & Male & 67 & Senior High School \\
P2 & Mr. S & Male & 59 & Bachelor Degree \\
P3 & Mr. A & Male & 58 & Elementary School \\
P4 & Mr. N & Male & 57 & Master Degree \\
P5 & Mr. A & Male & 41 & Senior High School \\
P6 & Mrs. M & Female & 46 & Senior High School \\
\hline
\end{tabular}

Informants in this study were 6 people with the age of 41-67 years and living in the Bulukumba Regency. The educational background of the informants ranging from elementary, high school, undergraduate and postgraduate levels. One informant has undergone PCI 2 times, and 5 others 1 time. All informants are still taking medication until this day. The results of the study found themes regarding the quality of life of post PCI patients as follows:

1. Feeling Back to Normal after PCI

Based on the results of interviews with 6 informants who had undergone PCI, all patients stated that they felt better and could return to their normal activities as before suffering from coronary heart disease, although with some limitations recommended by the doctor. As the informants said:

A. $\mathrm{P} 1$

"Alhamdulillah.. Alhamdulillah.. eee.. iya banyakki perubahan. Tapi ee.. yang namanya orang tua, ada kalanya enak-enak dirasaa.. ee.. sekitar 75\% mungkin perbedaannya dibandingkan dulu-dulu itu". 
B. P2

"Alhamdulillah lebih baik mi saya rasa.. aman ji saya rasa... jadi saya selalu ji bersyukur".

C. P3

"Syukur Alhamdulillah bagusmi.. lebih bagusmi..".

D. P4

"Sudah Alhamdulillah.. lebih enak.. lebih bebas saya beraktivitas. Tapi tetap dalam batasan... artinya sudah normal semua saya rasa toh"

E. P5

"Ya ituu.. ee.. yang jelasnya eee.. saya rasakan lebih bagus setelah pasang ring dibanding setelah terjadi serangan, sebelum pasang ring"

F. P6

"Alhamdulillah... sama seperti dulu sebelum sakit yang serangan jantung itu.. malah lebih baik saya rasa karna lebih sehat"

This shows that the provision of PCI to overcome blockage of blood vessels in the heart is the right thing to do. Besides being safe, this procedure is also not a surgical procedure, so it is called a non-surgical intervention procedure that uses a catheter to widen or open coronary blood vessels that are narrowed due to plaque buildup (atherosclerosis) using balloons or stents.

2. Sleep Pattern Improved after PCI

The recovery process requires a better quality and quantity of sleep than the needs of a healthy person. However, from the results of interviews that have been conducted, several informants stated that they experienced sleep disturbances after undergoing PCI. This is due to several reasons. As two informants said:

A. P5

"Pola tidur saya itu dari dulu kayak susah tidur.. sudah lebih 10 tahun".

B. P6

"Kalo itu pola tidur semenjak anu.. otomatis terganggu kadang itu, maksudnya insomnia pasti.. selama konsumsi obat itu pastii".

However, based on the results of the study, 4 out of 6 informants revealed that they had better sleep quality. As the informant said:

A. P1

"Tidur.. enakji.. enak tidur iyya enak.. karna kalo duduk-dudukka disitu nonton, 
biasaka tertidur".

B. P2

"Kalo sekarang beda iyya.. kah selalu mau ngantuk... pengaruh obat atau bagaimana..".

C. P3

"Syukur Alhamdulillah baekji.. iye bagusji.. biasa kalo mau buang air kecil toh, itu kasi bangunki".

D. P4

"Bagus juga.. nda pernah terganggu.. ballo tinro ku".

The results of this study indicate that most post-PCI patients have good sleep quality. This study is in line with the results of the analysis of the relationship between sleep quality and the incidence of heart attacks by (Dyah Yuspitasari, Zainab, 2018) which found that 8 out of 8 (100\%) good sleep quality did not experience repeated attacks. Meanwhile, among informants with poor sleep quality, 7 out of 27 (42.9\%) did not experience repeated attacks. The results of the Chi-Square test obtained p-value 0.000 with a significance level $(\alpha)=0.05$. The results of statistical tests have a value of

(p) $<0.05$, then Ho is rejected, which means there is a relationship between sleep quality and the incidence of heart attacks. So it can be concluded that patients who have undergone PCI have better sleep quality.

3. Pain that sometimes occurs after PCI

Of the many changes that were felt by the six informants, there were 5 informants who revealed that there was still pain after undergoing PCI. As informant said:

A. P1

"Biasa bagus, biasa ada nyeri-nyeri... tapi setelah pasang cincin yang kedua ini, nda mentong bisa ku tahan kalo datang sakitnya... itu saya pikir, kenapa ini sakit, sedangkan yang dulu waktu pertama tidak sakit ji. Tapi tidakji karna sekali-sekali ji datang sakitna. Ada ji juga obat dikasihkan sama dokter... kalo itu ku minum langsungmi baek kurasa."

4. P3

"Biasa sedikit-sedikit nyeri.. ta sebentar ji toh.. kalo datang lagi itu anunya, minumka lagi obat itu yang dibawah lidah".

5. P4

"Artinya pernah itu anu.. seakan-akan mengingat kesakitan waktu itu ji toh." 
6. P5

"Kalo sakitnya memang ada... kadang-kadang biasaa... kadang-kadang sering muncul... ndatau mungkin pengaruhnya itu cincin apa saya nda tau.. sakit-sakit anuu.. kayak semacam tertusuk-tusuk.. ganti-gantian".

7. P6

“Sekarang kadang... kecuali kalo misalnya agak-agak capek, karna nyeri... tapi yaa tidak sampe nyeri bagaimana seperti dulu sebelum pasang too..".

The pain that arises in the patient's chest after undergoing PCI can be caused by many things, one of which is anxiety, emotion, stress and fatigue. From the results of this study, the researcher assumes that post-PCI patients should not have recurrent chest pain if the informant always takes medication regularly. So it is necessary to look at the history of taking medication from the informant whether it is regular or not, because patients with low compliance will be prone to re-stenosis of the stent. Therefore, the patient must always be controlled, whether there is a new stenosis at a different locationor in the same location.

\section{CONCLUSIONS}

After undergoing the PCI procedure, it was found that the patients had a much better feeling, namely feeling like they were back to normal to be able to carry out their activities as before, the informants stated that most of them had changes in their sleep patterns that were better than before, and each informant stated that that they still have a few complaints about pain in their chest after undergoing PCI action, this can be caused by several things, one of which is non-adherence in taking medication. It is recommended for patients who have undergone PCI, should be more enthusiastic and remain optimistic in living life. And nurses are expected to be able to provide optimal service to patients who have undergone PCI, especially in helping carry out cardiac rehabilitation and providing confidence to patients in taking medication.

\section{REFERENCES}

Arni, A., \& Wagustina, S. (2019). Pengaruh Obesitas Terhadap Kejadian Penyakit Jantung Koroner (PJK) Di Puskesmas Darul Imarah Aceh Besar.

Dyah Yuspitasari, Zainab, E. S. (2018). Hubungan Kualitas Tidur Dengan Kejadian Serangan Jantung Pada Pasien Infark Miokard Akut Di RSUD Ulin Banjarmasin.

Muthmainnah, Q., Keperawatan, P. S., Kesehatan, F. I., \& Surakarta, U. M. (2019).

Gambaran faktor risiko kejadian penyakit jantung koroner. 
Oktaviono, Y. H. (2020). Komplikasi pada Intervensi Koroner Perkutan.

PERKI, (Perhimpunan dokter spesialis kardiovaskular indonesia). (2020). IndonesianHeart Association.

Susilo, C. (2015). Identifikasi Faktor Usia, Jenis Kelamin Dengan Luas Infark Miokard Pada Penyakit Jantung Koroner (PJK) Di Ruang Iccu RSD DR. Soebandi Jember.

Ully Hutagulung, R., Sri Susilaningsih, F., \& Mardiyah, A. (2014). Kualitas Hidup PasienPascaintervensi Koroner Perkutan. 